\title{
Article
}

\section{The Synergy of Financial Sector Development and Information Sharing in Financial Access: Propositions and Empirical Evidence}

Asongu, Simplice A. and Nwachukwu, Jacinta Chikaodi

Available at http://clok.uclan.ac.uk/25010/

Asongu, Simplice A. and Nwachukwu, Jacinta Chikaodi ORCID: 0000-00032987-9242 (2017) The Synergy of Financial Sector Development and Information Sharing in Financial Access: Propositions and Empirical Evidence. Research in International Business and Finance, 40 . pp. 242-258. ISSN 02755319

It is advisable to refer to the publisher's version if you intend to cite from the work. http://dx.doi.org/10.1016/j.ribaf.2017.03.001

For more information about UCLan's research in this area go to http://www.uclan.ac.uk/researchgroups/ and search for <name of research Group>.

For information about Research generally at UCLan please go to http://www.uclan.ac.uk/research/

All outputs in CLoK are protected by Intellectual Property Rights law, including Copyright law. Copyright, IPR and Moral Rights for the works on this site are retained by the individual authors and/or other copyright owners. Terms and conditions for use of this material are defined in the policies page. 


\section{Accepted Manuscript}

Title: The Synergy of Financial Sector Development and Information Sharing in Financial Access: Propositions and Empirical Evidence

Author: Simplice A. Asongu Jacinta C. Nwachukwu

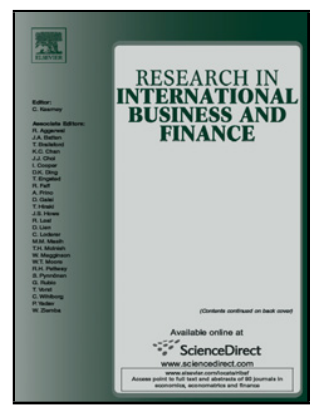

PII: S0275-5319(17)30175-7

DOI: http://dx.doi.org/doi:10.1016/j.ribaf.2017.03.001

Reference: RIBAF 613

To appear in: Research in International Business and Finance

Received date: 5-5-2016

Revised date: $30-7-2016$

Accepted date: 7-3-2017

Please cite this article as: Asongu, S.A., Nwachukwu, J.C.,The Synergy of Financial Sector Development and Information Sharing in Financial Access: Propositions and Empirical Evidence, Research in International Business and Finance (2017), http://dx.doi.org/10.1016/j.ribaf.2017.03.001

This is a PDF file of an unedited manuscript that has been accepted for publication. As a service to our customers we are providing this early version of the manuscript. The manuscript will undergo copyediting, typesetting, and review of the resulting proof before it is published in its final form. Please note that during the production process errors may be discovered which could affect the content, and all legal disclaimers that apply to the journal pertain. 


\title{
The Synergy of Financial Sector Development and Information Sharing in Financial Access: Propositions and Empirical Evidence
}

\author{
Simplice A. Asongu \\ African Governance and Development Institute, \\ P.O. Box 8413 Yaoundé, Cameroon. \\ E-mail: asongusimplice@yahoo.com \\ Tel : 0032473613172 \\ Jacinta C. Nwachukwu \\ Department of Economics, Finance and Accounting, \\ Faculty of Business, Environment and Society, \\ Coventry University \\ Priory Street, Coventry, CV1 5DH, UK \\ Email: jacinta.nwachukwu@coventry.ac.uk
}

\begin{abstract}
This study assesses the role of information sharing in financialization (or coexistence of financial sub-systems) for financial access. The empirical evidence is based on contemporary and non-contemporary Fixed Effects and Quantile regressions on 53 African countries for the period 2004-2011. The positive complementarity of information sharing offices (ISOs) and financial formalization is an increasing function of financial activity (or access to credit) whereas the negative complementarity of ISOs and financial informalization is a decreasing function of financial activity. In order to leverage on the synergy between ISO and financial formalization for enhanced financial access, some policy measures are proposed.
\end{abstract}

JEL Classification: G20; G29; L96; O40; O55

Keywords: Information Asymmetry; Financialization; Financial Access

\section{Acknowledgment}

-The authors are indebted to the editor and referees for constructive comments. 


\section{دريافت فورى ـ ـ متن كامل مقاله}

\section{ISIArticles}

مرجع مقالات تخصصى ايران

ل امكان دانلود نسخه تمام متن مقالات انكليسى ل امكان دانلود نسخه ترجمه شده مقالات ل يذيرش سفارش ترجمه تخصصى $\checkmark$ ل امكان جستجو در آرشيو جامعى از صدها موضوع و هزاران مقاله ل امكان دانلود رايكان r صفحه اول هر مقاله

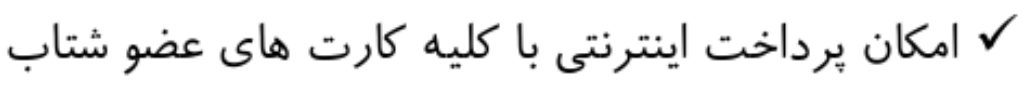
ل دانلود فورى مقاله پِ از برداخت آنلاين

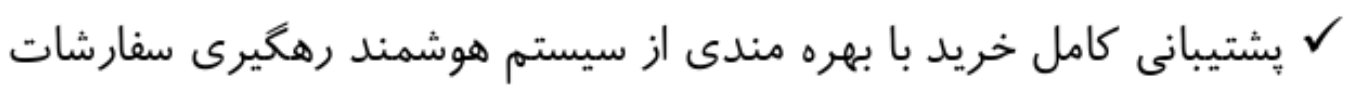

